\title{
Environmental justice as a (potentially) hegemonic concept: a historical look at competing interests between the MST and indigenous people in Brazil
}

\section{Yogi Hale Hendlin}

To cite this article: Yogi Hale Hendlin (2019) Environmental justice as a (potentially) hegemonic concept: a historical look at competing interests between the MST and indigenous people in Brazil, Local Environment, 24:2, 113-128, DOI: 10.1080/13549839.2018.1488823

To link to this article: https://doi.org/10.1080/13549839.2018.1488823

曲 Published online: 27 Jun 2018.

Submit your article to this journal

Џ Article views: 97

View Crossmark data $\complement$ 


\title{
Environmental justice as a (potentially) hegemonic concept: a historical look at competing interests between the MST and indigenous people in Brazil
}

\author{
Yogi Hale Hendlin \\ Department of Medicine, University of California, San Francisco, CA, USA
}

\begin{abstract}
This article explores the need to recognise and compensate the plurality of environmental justice claims, while paying close attention to the outcomes of the most marginalised groups - cultural and ecological - in political decision-making to avoid vestiges of hegemony. The early history of the Movimiento dos Trabalhadores Rurais sem Terra (MST) serves as a case study in which environmental justice claims clash with indigenous rights claims. In recent decades, the MST has refused settling Amazonian indigenous territories, consistent with the organisation's Via Campesina platform, which focuses on redistributing the $50 \%$ of national territory controlled privately by Brazil's richest $4 \%$. Yet, in the 1970 s and early 1980s, Brazil's military government pitted landless peasants and indigenous people's struggles against each other, circumventing land reform potentially disruptive to the country's de facto colonial fazenda land system. This tactic pressured competing groups - landless peasants and indigenous people - to fight against each other, concluding predictably: the most powerful factions ended up getting their way, conceding less in negotiations than their less-advantageously positioned, marginalised counterparts. When marginalised groups gain concessions in environmental justice struggles, often the goods comprising those concessions come at a cost to marginalised groups with even less political visibility. Hegemonic structures of power remain non-negotiable in the process of alleviating other injustices in perceived zero-sum politics. Such systemic displacement and dispersion of violence in systems built on violence suggests hegemony affects not just to other marginalised groups, but to nonhumans too.
\end{abstract}

\section{ARTICLE HISTORY}

Received 4 February 2017

Accepted 6 June 2018

\section{KEYWORDS}

MST; Brazil; land rights; hegemony; indigenous commons

\section{Introduction}

Environmental justice movements are often portrayed as harmonious coalitions allied to surmount the injustices of a clear opponent (Cole and Foster 2001; Szasz 1994). Such a frame, however, tends to gloss over real conflicts internal to environmental justice movements. I argue that Gramsci's description of hegemony goes some way to explain these suppressed inner conflicts. Focusing on a case study examining the birth of Brazil's landless peasants' movement, the Movimiento dos Trabalhadores Rurais sem Terra (MST) emerged from a territorial clash against indigenous people. This unexpected origin of the MST is analysed to describe how hegemonic orders created a division between these two very differently motivated groups that became de facto and later de jure premier environmental justice movements in Brazil, and internationally, since the late 1970s and early 1980s. 
Government and corporate pressure on indigenous and peasant groups led to conflict and animosity, with each marginalised group guided to obtain gains at the expense, rather than in support, of the other. This example of infighting in environmental justice movements - fighting not to be the lowest rung on the political ladder - emphasises the strategic and ethical necessity for solidarity among disparate environmentally-marginalised groups, to redirect demands for concessions towards the shared sources of oppression.

The question of inclusion and differential privilege is at stake in any treatment of environmental justice; and is especially present for any consideration of the tensions and compromises observed in pluralising the topic, looking at environmental justice from multiple vantage points without succumbing to overzealously defending a particular interpretation of events. As the concept has emerged, environmental justice does not only consider the equitable redistribution of environmental goods and bads, but also the recognition of lifeways (such as indigenous cultures) embedded in particular ecologies (Schlosberg 2007). An example of environmental injustice, the fazenda land tenure system in Brazil betrays its colonial origins, as $46 \%$ of the country's territory is held by the political and economic elite, who received it historically from colonial landed gentry (Fernandes 2008). To protect the ruling class's fazendas and to economically develop the Amazon, a territory continually occupied by indigenous peoples, the historical Brazilian military government attempted to evade threats to their territorial power by deflecting protesting peasants through sending them on colonisation journeys to the Amazon. These peasants, hungry for land, were often provoked by the Brazilian government to occupy indigenous territories.

While according to its Via Campesina platform, the MST has long refused colonisation of the Amazonas, examining how the MST \& indigenous people's struggles were pitted against each other by the mediating power of the Brazilian government in the 1970 s and early 1980 s contains valuable lessons for better dealing with competing environmental justice claims. The complex events surrounding the founding of the MST exhibit an in-group/out-group approach to land reform rather than solidarity between peasants and indigenous peoples.

In this particular case of the MST's founding, degeneration of cultural and ecological dialogue resulted as both indigenous and peasant groups became ensnared in a logic of zero-sum property rights based on the fecundity-depleting requirements of "effective use" land policies mandating land exploitation to secure land tenure. In the transition from the claim to territory based on longterm habitation and conservation to property rights based on knowledge of how to manipulate existing political, economic, cultural, and juridical structures imposed on land, those least established in these structures and hence most vulnerable to their predatory tendencies, suffered most. Amongst the losers of this inscription of land into the state's bureaucratic social systems was, of course, the land itself and the multitudinous nonhuman beings dwelling in it.

\section{The theory of hegemony and environmental justice movements}

Despite its claims of remedying wrongs inflicted upon those groups systematically subjected to harmful environmental degradation, competing interests in environmental justice often resolve in ways similar to other issues in politics: the loudest voices with the most power leverage the most concessions, or at least, concede less (and gain more) in negotiations than their less-advantageously positioned counterparts. The problem of power for marginalised peoples, in other words, is that even if they successfully achieve political, economic, or territorial goals, often the actual material goods they receive comes as much at a cost to privileged hegemonic classes as it does from those groups even further marginalised and less politically visible than the receiving group. This zero-sum politics immobilises certain existing social structures and relations of power as non-negotiable, even in putatively transformative processes alleviating longstanding injustices. Political reconciliations which perpetuate or even entrench hierarchies despite localised political, economic, or social gains, signal the quintessence of hegemony - the systemic unidirectional displacement and 
dispersion of violence in a system built on violence (Butler, Laclau, and Žižek 2000; Critchley and Marchart 2012; Gramsci 1970; Laclau and Mouffe 1985). ${ }^{1}$

Conceptually delineated by Gramsci and elaborated by Laclau and Mouffe, the concept of hegemony applies to social movements successfully pressing for redistributed power relations when distribution occurs at the expense of "downstream" people and natural beings rather than at the expense of resources accumulated "upstream". Hegemony can be encapsulated through the following example: the company boss operating in a competitive atmosphere pressures the manager for more production; the manager stresses the employee to work harder; the disgruntled employee goes home and yells at her husband to blow off steam; the angry husband spanks their child; and the distressed child delivers this passed-down aggression and kicks the dog. It is not as if any one person in this chain is solely responsible, or directs this process. While this particular example appears "top-down", hegemony is just as often horizontal or diagonal in application. At any point in the chain, any of the actors have - in theory - the capacity to interrupt the chain of hegemony, disrupting the perpetuation of systemic violence.

What is striking about the MST, is that in recent history, they are the most successful group to understand the political explosiveness and effectiveness of "the idea of occupation as critique: namely, the use of the idea of something being already taken as a rejection of the claims of a hegemonic power" (Fitzmaurice 2014, 32). Such a power warrants great discernment. When redistributing land entails petitioners taking commons inhabited by groups with even less access to power, such transfers do not narrow entrenched power asymmetries as would be the case when occupying excess land managed by elites; in these cases, instead of challenging preexisting hegemonic structures, these takings perpetuate them. Hegemony is at play when the extra environmental "goods" provided to protesting groups come from increased extraction from other realms: the social and ecological peripheries.

Of course, hegemonic structures are perpetuated not just between social groups but within social movements, as elite management of movements often subordinates some actors (such as women) to (often male) movement leaders' exigencies and strategies (DeVore 2016; Suárez 2006). In such circumstances, we can refer to environmental justice movements that may not necessarily be hegemonic between groups, but within them (Fraser 2003). In other cases perpetuating hegemony in environmental justice between humans and the environment, concessions won are bought at the price of further extraction or expropriation from environmental commons (Ostrom 1990, $11 \mathrm{ff}$ ). Still other forms of hegemony, occurring between groups in environmental justice movements, as spotlighted in this case of the MST and indigenous Brazilians, intentionally or unintentionally sacrifice the environmental safety and territory of those classes even less politically visible or with less political purchase, an always unstable position (DeVore 2016; Diomo 1995; Scott 1999). Explored here is the way elites deflect struggles for redistribution, especially for land, away from challenging existing hegemonic orders and instead set empowered underclasses against disempowered underclasses and the environment.

Proponents of environmental justice benefit from assiduously attending to land struggles' processes and outcomes to ensure that concessions do not break social or ecological bonds of solidarity, which might ultimately undermine the overarching campaign for justice. While in recent years neoliberalism has garnered the most attention as a framework to analyse and critique actual existing injustices and their perpetuating mechanisms in environmental justice discourses (Harvey 2006, 2007; Nixon 2011; Vergara-Camus 2014), the frame of hegemony captures internal ways in which power creates chains of subjugation which predate and undergird the rise of totalising neoliberal frameworks. The reoccurring crises of reconfiguration of power since colonialism have tended to favour elite capture for private interests, rather than democratic portioning.

Gramsci's $(1999,206)$ insight that "[t]he history of subaltern social groups is necessarily fragmented and episodic" serves to critically reflect on the MST's retrospective smoothing of their narrative. The MST as an organisation has not remained constant but has metamorphosed over decades. They have gone from a marginalised radical group of peasants physically occupying land to a globally 
ramifying movement routinised within Brazil's major leftwing Worker's Party (Partido dos Trabalhadores). Gramsci warns against the "tendency to (at least in provisional stages) unification in the historical activity of these groups", as the messiness of unwritten histories composed into cohesive, critical narratives "therefore can only be demonstrated when an historical cycle is completed and this cycle culminates in a success" $(1999,206-207)$. While the MST is very much still alive as a movement, its routinisation in and cooptation by party politics has substantially shifted its trajectory, even as it remains revolutionary out of necessity under the Temer interim government. Critically analysing the MST's overarching self-description reminds us that subaltern histories are not necessarily more transparent and self-reflexive than dominant ones.

The "integral historian", as Gramsci $(1999,207)$ calls her, must therefore be alert to the inertia of historical narratives perpetuating the obfuscation of injustices internal to even successful social movements. ${ }^{2}$ Hegemony's insidious structure is effective because it infiltrates and reproduces structural violence fractally on increasingly vulnerable populations. While the MST has proved reflective in owning up to moments of reproducing patterns of oppression (Stédile and Fernandes 1999; VergaraCamus 2014), it has not been immune to recasting unflattering events in more advantageous and simplified narratives.

\section{Hegemonic environmental justice: pitting peasants against indigenous rights}

\section{Precursors to the MST}

Almost nowhere in Brazil did land redistribution historically include indigenous people. Indigenous peoples became first recognised in global international politics during the 1970s and 1980s, as a result of international actors pressuring states to gesture at respecting indigenous peoples' unique rights of land sovereignty, even as many of those same international actors hypocritically refused to recognise indigenous rights domestically (Merlan 2009; Stocks 2005). Even so, the concessions landless peasants were able to extract from large-scale landholders occurred under a neocolonial property regime systematically excluding the commons-type land arrangements indigenous people possessed.

Brazilian elites' calculated construction of a rivalry between peasants and indigenous peoples to deflect peasant occupation from their own unproductive large landholdings (fazendas, known in the rest of Latin America as latifundios) ${ }^{3}$ (Branford and Glock 1986), epitomises the abuse of political power to engineer a hegemonic version of environmental justice. Perfecto, Vandermeer, and Wright $(2009,111)$ describe how

one of the chief tactics of the national government to try to forestall the development of a new land reform movement was to offer land grants in the Amazon. In 1970, Brazil's President announced that in the Amazon, Brazil could provide "a land without people for a people without land". "The land without people" being President Medici's quite inaccurate description of the Amazon.

The impact of this displacement of landless peasants onto indigenous peoples' lands, diverting attention away from the fallow fazendas originally targeted, had devastating effects on the cultural and ecological integrity of the Amazonas.

After the 1964 military coup, many Brazilian peasants experienced themselves displaced from the land they had tended for generations. The sem-terra (without land), as they were called, sought to organise in a manner separately from the Ligas Camponesas, the rural trade unions in the 1950s which adhered to strict national trade union political and juridical rules (Branford and Rocha 2002, $23 \mathrm{ff}$ ). Formed to combat exploitation from ruling elite landholders, these peasant leagues were often attacked, their leaders assassinated, and often prohibited from officially organising altogether. In a 1976 report, Brazil's progressive Catholic Church condemned government attacks on rural workers as widening rather than reducing income gaps (Diomo 1995).

Separately from the peasant leagues, and with strong and often surreptitious support in the late 1960 s through the 1980 s by many liberation theology Catholic priests, landless peasants slowly 
became organised. A unique, revolutionary form of Catholicism that arose in Latin America in the 1950 s and 60's, liberation theology takes the economic, political, and spiritual liberation of the oppressed as its mission. Because of the political power of the Catholic Church during these decades, this religious activist movement became a potent progenitor and ally for social justice movements throughout Latin America (Poletto and Canuto 2002). Houtzager $(2005,14)$ notes that "[t]he Church - as Catholicism as a symbolic order with deep resonance among 'the people' - provided much of the structural and ideational underpinnings of the [MST's political and juridical] field", and "also had a strong influence from the Gramscian left, which may help account for the strong (and somewhat paradoxical) emphasis on rights". The MST's inscription in the prevailing Brazilian legal systems was tense at their inception, and remains ambiguous in some areas.

\section{Land redistribution under Brazil's military government}

The events leading to the MST's founding are complicated by the organisation's development from peasants who were displaced as a result of the Brazilian government's afterthought to recognise the territorial rights of indigenous people. Thus, the Brazilian government which had motivated peasants to Amazonian lands, subsequently forcibly removed the peasants who had squatted these indigenous territories (Branford and Glock 1986).

At the beginning of 1970s, many indigenous groups in Brazil remained "uncontacted" (Branford and Rocha 2002). Yet, many indigenous tribes had long been inundated during the twentieth century by migrant rubber tappers. Responding to the pressure of the fazenda system excluding them from local arable land seized by elites, rubber tapper migrations created pressures on the Amazonian populations in the regions they settled. While Brazil's rubber tappers' movement more recently has been successful in gaining political visibility for their own compromised position through "merging its claims with environmental and indigenous rights issues" (Johnston and Almeida 2006, 10), this group draws opportunistically on the political capital of the same victims their profession historically displaced.

Settler rubber tappers, foresters, and farmers often encountered contrasting imperatives. On the one hand, they were tacitly encouraged to "colonize" the South American "Heart of Darkness" of the Brazilian Amazon, making economically legible and mobile previously impenetrable territories (Zhouri 2010). On the other hand, because often their land holding property rights were tacit and tentative - an optimistic form of squatters' rights - industrious entrepreneurial peasant farmers were at the mercy of the Brazilian government's national forest industries reclaiming their holdings, polluting their land through adjacent mining activity, or losing it to private companies or major landholders showing up and asserting their absentee ownership on the lands (Branford and Glock 1986; Branford and Rocha 2002).

Thus, this process of deterritorialising and reterritorialising lands that prima facie were at the dispensation of an elite-controlled federal government, displaced a variety of marginalised groups with each decision. Such a frustrating situation for both peasants and indigenous peoples vis-à-vis industrial and fazendeiro interests engendered scepticism towards the idea that both groups could receive the protections and holdings they sought. Missing from these events was a direct confrontation with the large landholders that made up (and still make up) the majority of land ownership in the country. The MST, however, would soon fill this gap by turning the question of land acquisition and usage back on the very entities whose interests governed state decision-making. The MST would present the case that massive unused parcels of land held by absentee landowners were derelict, and through this unproductivity, they argued, the owners forfeited their land rights. Hence, peasant farmers eager to make productive use of these lands had an imperative to do so (Benford and Snow 2000; Houtzager 2005).

While colonialism had already reduced the 5 million or so indigenous Brazilians to less than 200,000 by the twentieth century (Branford and Glock 1986), the further incursion of rubber tappers since the 1880s, gold miners during the 1950s-1980s, and unorganised landless peasants 
from the 1960s on, further stripped them of their territories. This forced many tribes onto reservations or into cities as their traditional lands were usurped and denatured (Branford and Glock 1986). During the military dictatorship (1964-1985), vast amounts of public land fell into the hands of a few private conglomerates. In the Brazilian state of Acre, for example, in $197175 \%$ of the territory was state owned, while by $197580 \%$ of the territory had transferred to private corporations (Hecht 1989). With a quickly diminishing available resource base, both landless peasants and indigenous communities were vying for the same parcels of a shrinking communal land base.

Indigenous communal territorial rights, when recognised at all, operate under a non-Eurocentric land ethic difficult to square with private property. When pitted against the quasi-private quasi-collective gray-area of land rights, the MST often finds its members engaged in, communal land rights and land rights by occupation have been tricky to amicably reconcile. Indigenous peoples and peasants' shared plight stems from elite corporate development and transformation of the Amazon and the industrialisation of extraction of ecological commons. Yet, because such economic forces are formidably backed by political power and sanctioned violence, the path of least resistance for landless peasants and indigenous peoples alike has often been to hold each other accountable for transgressions rather than confronting the architectonic entities driving the scarcity of land (Branford and Rocha 2002; Wright and Wolford 2003). These conflicting rights regimes are based often on contrasting legal models, the MST's ultimately resting on accepting the prevailing ownership recognition model of private property rights, while indigenous communities regularly ask for and are granted claims based on communal territorial rights.

Brazil's land settlement programme under the Medici government (1970-1974) brought landless families from northeast Brazil to the Amazon basin under a land colonisation scheme granting plots in a region the immigrant peasants were poorly prepared for (Jepson 2006). According to Branford and Rocha $(2002,5)$, this programme was intended to "guarantee a pool of labour for the ambitious mining, ranching, farming and logging projects that the military planned in the region". The peasant settlers were - unbeknownst to them - instrumentally used to clear the Amazon jungle territories they were granted. They often encountered the land difficult to work with as they had little local knowledge of how to work the loamy soils very different from the dry northeast. Motivating the peasants to relocate was a necessary sequential step in a corporate plan aimed at getting the peasants to clear the land before the legal corporate owner of the land drove the peasants off the now conveniently cleared land (Stocks 2005). These manipulative "colonization" projects meant that peasants were "bullied into travelling to an unknown, hostile region at the other end of the country" (Branford and Rocha 2002, 6), resulting in a cheap captive labour force of dislocated peasants, searching for land wherever they could find it.

\section{Hegemonic environmental justice and the birth of the MST}

If beginnings are telling, the MST's formal coalescence in reaction to the May 1978 expulsion of peasant families from the indigenous Kaingang Indian Reserve at Nonoaí, in the region of Rio Grande do Sul, divulges a deeper schism in indigenous-peasant solidarity than frequently projected by MST official history (Kujawa 2015). The Kaingang tribe had long dealt with illegal settlers on their lands, peasants who had lost their land to corporations, or who had relocated and then found their promise of guaranteed land broken. Since the 1940s, settler peasants directed to the Amazon by the Brazilian government had begun encroaching on Kaingang territory created in 1847 as an official indigenous land claim, the Reserva Indígena do Nonoaí (Fernandes 2000, 50-51). Despite some success in the 1960s to maintain their territorial lands with the help of government agencies tasked with protecting indigenous peoples and their interests, many peasants remained on their lands, and settler peasants kept arriving. Since 1974 the Kaingang had been working with a liberation theology group, CIMI (Consehlo Indiginista Missionário), to expel the settler families (Fernandes 2000).

In the interim, to cope with a constant stream of peasant immigrants settling on their legallyappointed lands, the Kaingang set up their own informal (and extra-legal) rentier system, portioning 
out small plots for peasants to farm and minimally log in exchange for monthly payments (Wright and Wolford 2003). The Kaingangs' uneasy compromise was brokered, however, without permission from the sometimes paternalistic National Indian Foundation FUNAI (Fundação Nacional do Índio), which prohibited the selling or renting of tribal reserve lands to settlers. As deforestation reached alarming levels, and new waves of peasants began occupying rather than renting reserve lands, planting crops for commercial purposes and unprecedentedly spraying pesticides, "poisoning local streams and lakes, killing the fish and birds", the Kainang diet and health became compromised (Wright and Wolford 2003, 16). Upset that peasants circumvented their territorial rights without permission or payment, and dismayed that their local ecology was quickly deteriorating, the Kaingang reneged on their existing rentier agreements and demanded that all settler peasants exit their territories (Wright and Wolford 2003).

When FUNAI was slow act on their behalf to expel the settlers, the Kaingang physically attacked peasants refusing to leave their territories. This action motivated FUNAI to act as an intermediary, and in the span of a month, the Kaingang and eventually the Brazilian government deposed 1,800 families from the reserve, leading to spates of violence between the peasants and the Kaingang (Wright and Wolford 2003). These bloody events required government intervention to prevent continued violence between the angry, now homeless peasants, and the Kaingang. This resulted in the government eventually bussing half of the displaced peasants to government colonisation projects in other parts of the Amazon. Not just in Nonoaí, but elsewhere too these land claims clashes between those serially suffering lost land took place (Stédile and Fernandes 1999). Kujawa (2015, 72) notes that the "territorial policies developed by the State, [...] paradoxically give [...] the same space, in different historic moments, to indigenous peoples and to farmers". Especially at the colonial frontier, land claims malleable according to the exigencies of the state, created unnecessary territorial conflicts between indigenous land rights and peasant settlers.

Solidarity is the highest virtue of counter-hegemonic movements. And yet, the dawn of the MST emerged from a barely averted counter-attack to resettle the Nonoai reserve. With the help of local priests and political activists, the enraged displaced peasants only reluctantly turned away from continued violent confrontation with the Kaingang, on condition of the opportunity to occupy stateowned and large derelict private landholdings (Wright and Wolford 2003, 18). The MST coalesced on this new tactic of going after fazendas only after reluctantly deciding against revenge on the Kaingang.

While peasants traditionally occupied the lowest status in Brazil's quite rigid class structure, indigenous peoples, because they often did not speak Portuguese, were seldom even classed as Brazilian citizens (Perruci 1999, 167). ${ }^{4}$ This hierarchy of perceived power and privilege contributed to the entitlement that the socially-enculturated if landless Brazilian peasants could justifiably take indigenous people's land. The Kaingang, like other indigenous tribes, did not arise from the same colonial form of property rights shared by the Brazilian state and its linguistic-cultural citizens, but in order to maintain any claim to their territory they were forced to translate their principles of habitation into legalistic property terms legible to the state and would-be settlers. It is this instance of the landless peasants, unjustly forced off their elite-controlled tenant-farms, unceremoniously settling on Kaingang lands, that constitutes an act of hegemonic environmental injustice.

The competing claims of both the MST and the Kaingang centred around distributive justice. But as external forces confined them to struggle against each other for limited territory, their claims shifted, concentrating on procedural justice. While the landless peasants were already economically and psychologically inscribed in a system of capital and private property that regarded land as a resource to extract and sell goods from, their concepts of socio-economic standards and systems of property became more easily identifiable for the state than those of the Kaingang. The conflicts between the landless peasants and the indigenous tribe also revolved around which way of life receives recognition sufficient for the state to intervene to preserve it.

From this clash, the peasants transformed their aims and strategies to achieve their first successful occupation of fazenda land five years later, having learned (with the support of the priests aiding 
them) that occupying unused estates both attacked the power structures keeping them from land, and avoided territorial disputes with indigenous peoples. Since receiving the shock of expulsion from indigenous lands, landless peasants in the interceding decades have on the whole, but not always, allied with indigenous peoples against their common threats to environmental justice.

\section{Landless peasants as a symptom, not a cause, of indigenous dispossession}

While indigenous peoples continue to face encroaching settler peasants, the greatest conflicts they confront involve large-scale production, transnational corporations, and agribusiness (Jepson 2006; Kujawa 2015). Some of the most egregious human rights violations and takings of indigenous land in recent decades include soy agribusiness seizing the territory of the Marawatsede in northeastern Mato Grosso, sugarcane agribusiness taking territory from Guarani peoples in Mato Grosso do Sul, and the Belo Monte dam construction in Pará that has displaced more than 60,000 indigenous peoples by flooding indigenous territories (DeVore 2016; Jepson 2006; Oliveira 2013; Zhouri 2010). In these three cases, consistent with its Via Campesina social code, the MST has actively fought for indigenous territorial rights in solidarity against exploitative state and corporate projects.

Landless peasants and indigenous groups threatened with the removal of their territories are similar in their calls for justice and basic rights, even if the substance of these claims manifests differently. The initial post-colonial/neocolonial land distribution scheme of the independent Brazilian state sowed the seeds for many of the ensuing problems of environmental justice these two groups face currently. Indigenous claims for sovereignty over their lands and for the survival of their people and culture clash with the desperation of peasants facing an exploitative capitalistfeudal economic system fixated on productivity rather than reproductivity (Biesecker and Hoffmeister 2010). While migrating populations left other areas principally out of duress, the hegemony of the land-colonising processes meant that Brazil's landless peasantry were often led to believe they had little option but to usurp Amazonian lands from indigenous populations; or, when not directly taking active territories, it was their encroachment on frontiers (encouraged by the state) that paved the way (sometimes quite literally) for more organised extractive industries (Branford and Rocha 2002).

Such path-breaking in the previously impenetrable Amazon and Pantanal also often occurred the other way around, with extractive industries opening the way for migrant homesteading. The correlation, if not causation, remains clear: where Brazilian nationals entered into territorial spaces previously occupied only by indigenous peoples (many who may have had no idea that they were in fact "Brazilian") ${ }^{5}$ or uninhabited, untouched (by non-indigenous hands) forest, such "primeval" forest soon became industrialised, and according to colonial models of use, productive (Hendlin 2014b).

Gold miners or garimpeiros, with ambiguous ties to the MST also invaded native territories and mined without consent from either local tribes or the government (Hecht and Cockburn 2010, 160). Many small-scale illegal miners and loggers have operated under the cover of the MST, even as the MST denounces such actions (Wright and Wolford 2003). The major displacements of tenant farmers starting in the 1960s drove many former farmers "who lost their livelihood [] to join the gold rush in the Amazon" (Branford and Rocha 2002, 48).

As recent as 2017, "uncontacted" tribes continue to be massacred by garimpeiros encroaching on their territory to mine for gold (Agence France-Presse 2017). The boundary demarcating who falls in or out of the MST movement is porous and blurred. The contested boundaries of this movement have often been taken advantage of by large extractive corporations seeing opportunities in the fragmentation and disagreements internal to the movement (Filho et al. 2015; Gamba and Costa Ribeiro 2017). The vulnerability of those not in positions of leadership or relative power within the MST raises questions regarding procedural justice and recognition for those marginalised within the group (Suárez 2006), as well as non-members (such as indigenous tribes) who may be played off the MST politically to the detriment of both environmental justice movements. 
Vis-à-vis land grabs, the conversion of terra communis into terra nullius encompasses the "transfer of ownership, use rights and control over resources that were once publicly or privately owned - or not even the subject of ownership - from the poor (or everyone including the poor) into the hands of the powerful" (Fairhead, Leach, and Scoones 2012, 238). This clause, "or everyone including the poor" highlights that communal lands are not owned, properly speaking, under a private property rights scheme that only valuates land pertaining to particular owners (Hendlin 2014b). Instituting defined property rights for terrains where prior these did not exist, results in the people living in or around those territories, as well as the area's natural (nonhuman) inhabitants, losing their habitat. Generally, land is de facto taken away from such stakeholders, even as de jure, because the land did not belong to anyone, there can be no rights-holder to take the land away from.

While there are strong arguments that can be made from the environmental point of view for supporting MST land devolution as opposed to continued industrial-level extraction or farming, there is also the question that in many instances (especially historically), peasants (who might see themselves as represented by the MST) through encroachment have contributed to indigenous territorial fragmentation and diaspora. When the Brazilian government legally recognises the territorial rights of indigenous peoples, as it has several times, this often involves forcibly removing the peasants that had homesteaded on indigenous lands. While this helps the indigenous peoples, and ecologists might reasonably argue preserves a higher level of wilderness, such actions displace serially displaced peasants, regularly without giving them anywhere else to turn. Such ad hoc policies thus potentially repeat unjust settlement processes elsewhere, deferring the problem of being a landless farmer to some more obscure, less surveilled tract of land, where the people who might be inhabiting that space may be even less politically franchised, ad infinitum. Thus, some landless people have become landless as a result of delayed state recognition for the legal rights of the longstanding historical territorial inhabitants.

\section{The MST's uneven evolution}

The earlier years of the MST followed the immediate needs of peasants against eviction from their now strategically occupied fazenda lands, enduring the state and landowner violence that often accompanied it. In later years, as the group enjoyed substantial victories, MST subunits networked their short-term regional aspirations with a wider portfolio of social and ecological issues. These included specifically allying with forest peoples against expropriating their lands, and demanding that the government begin to sacrifice fazenda territories to meet their land needs - going to the heart of the colonialist matter - rather than displacing MST environmental justice claims through encouraging instead occupation of wild and/or indigenous territories (De Souza Martins 1990).

By the early 1980s the MST had distilled its tactics and ethos into a cohesive platform. Since then, the MST's principles and tactics have influenced rural and urban peasant movements around the world, working in direct action to reappropriate privatised public land for cooperative and communal small-scale agriculture. Through squatting land unused by fazendas as well as "wild" land often the home of indigenous people but not yet juridically designated with an official private owner, the MST successfully empowered between 800,000 and 1 million families to legally gain their own farmable land, totalling nearly 48 million hectares in Brazil between 1985 and 2006 (Fernandes 2008). The website they maintain, www.mst.org.br, houses an exhaustive source of information regarding their movement and its history. Reading it, one gets the distinct impression that the MST is and has been at the forefront of the environmental justice movement - which is true.

Yet, like all histories, theirs is written through a particular perspective. Even in their continued struggles, the MST frame their movement as a victorious one. Their substantial, permanent gains for millions of peasants attest to their role as a flagship environmental justice movement. While some historians call theirs a minor history, as opposed to the imperial narrative of History written by the persistently elite-driven Brazilian government, ${ }^{6}$ it is worth noting that in comparison with 
the majority of Brazil's indigenous population, the MST's story and their self-presentation of it reads nonetheless as written by victors.

The MST's claims to land were successful in part because despite claims to a revolutionary programme of emancipation from the inequalities rife in Brazil, it has managed to work closely with the country's unions, parties, clergy, and other power-brokers. One of its most powerful constituencies, the National Rubber Tappers' Council, has helped the MST in its protests to exert pressure on the Brazilian government in order to leverage redistributive gains.

While currently the MST is firm in its commitment to make use of fallow lands already under some sort of alleged use rather than appropriating virgin rainforest or indigenous areas (Stédile and Fernandes 1999), the political sequences of events that successively pass off unused or unusable land on MST members in order to appease their demands often includes the MST as a second-wave (and sometimes first-wave) of rainforest conversion constituency.

The MST's position as a genuine power the Brazilian state could not ignore, grew out of their "tactically flexible" structure "peopled with managers often as well-versed in revolutionary theory as would-be revolutionaries" (Maybury-Lewis 1994, 214). Yet still, far from entirely successful, their movement remained continuously vulnerable to the government's ability to "co-opt, encapsulate, or, if necessary, repress them" (Maybury-Lewis 1994, 214). While rooted in revolutionary transformative politics of Gramscian liberation theology and land occupation (Diomo 1995), the MST quite clearly has undergone a pragmatic turn as it has enjoyed political success. This has often lead to compromises of fulfilling specific member goals rather than holding out for the broader social changes originally sought. From the beginning, some MST factions have been more concerned with achieving their own material needs and buttressing their own regional power than sharing their land gains with others who were not directly involved in their campaigns and struggles. Especially in the early formation of the MST, solidarity as a movement took a secondary role to immediate material gain. One MST activist wrote in a MST newspaper, later reflecting on this period: "The conquest of land was the central question. The idea was: 'the day I get my plot of land all my problems are over.' It was a struggle for land not for agrarian reform" (CONCRAB 1995, 28).

Those less politically astute and motivated, especially indigenous populations that usually only fought back defensively rather than proactively, have sometimes been left outside of the negotiated treaties and pacts between the MST, private corporations, and the government. This is a common fate for indigenous groups not yet inscribed in and reproducing western hegemonic forms of power (Schröder 2016).

The reoccurring question of who is the MST, and what tradition they represent is raised by Martins, who calls the agglomeration that is the MST an "invention of tradition" rather than the result of some continuous, cohesive and delineable group of peasant workers (De Souza Martins 2002, 300; cf. Hobsbawm and Ranger 2012). The identity claims of the MST have not been that they are indigenous peoples who have had their communal lands lost, but that they are landless peasants that have been displaced and excluded from the fazenda system which Brazil anomalously in South America, has not yet abolished. Brazil has not instituted a major land reform overhaul since the postcolonial system of distributing land to wealthy politically-connected families was carried out in the nineteenth century.

The question of inclusion comes to a fore in Hecht's description of the Amazon as historically inhabited by a "large, complex peasantry formed from indigenous peoples; de-tribalised natives; runaway slaves; populations left in place after the various booms ebbed; the new colonists from the massive settlement and agrarian reform programmes, like the trans-Amazon highway; ethnic settlements like those of the Japanese and Mennonites; and a range of other migrants who followed the roads, the jobs and resources like gold, timber and coca" (Hecht 2015, 233). Parsing which groups are more representative of the MST, which less, and which are left out and at times have even been oppositional, can be difficult due to the porous and dynamic relationships these various groups sometimes have. This difficulty is compounded by the historical shift of the MST from a localised pro-peasant farmer movement to a more broad collectivist and revolutionary movement committed 
to solidarity with other marginalised rural peoples - indigenous and migrant. As identity politics began to play a larger role in the MST's self-understanding and individual members' identity, normative ideals of distributive justice have expanded to constrain the MST's marginalisation of potentially allied groups.

It remains unclear how the precarious relationship between the MST and indigenous communities will unfold. On the one hand, Brazil's latest Forest Code of 2012 forgives many settler peasants who have appropriated wild Amazonian land that was indigenous territory, thereby permanently reducing the amount of territory available to indigenous groups and for conservation efforts (Filho et al. 2015). On the other hand, the Forest Code has been heralded as pragmatic and tractable politics; the alternative would be confront violent resistance if the government had attempted to commandeer small landholder properties for indigenous communities or conservation (Gamba and Costa Ribeiro 2017). In exchange for forgiving illegal encroachment, the Brazilian government is demanding that small landholder's preserve up to $80 \%$ of their property as wild for ecological integrity, flora and fauna biodiversity, and carbon accreditation (should that scheme ever become an economic reality) (Soares-Filho et al. 2014). Thus, in giving up a strong commitment to indigenous land sovereignty and indigenous rights, as well as in exchange for large-scale ecological preservation, the Brazilian government is opting for a matrix ecology approach. Matrix ecology definitions of healthy ecosystems do not necessarily exclude productive (commercial) use. Understood as a patchwork of ecological islands that together form sufficient cohesion networks, such policies aim to fit in nature in the interstices of human activity (Perfecto, Vandermeer, and Wright 2009). Whether this environmental justice gain for peasant farmers is fair for indigenous forest peoples, is another matter.

\section{Discussion}

\section{Analysis}

In examining the history of Brazil's MST, especially the earlier years (late 1970s to the mid-1980s) when the exigencies of winning land concessions often outstripped solidarity with fellow peasants and indigenous people also facing encroachment, one can discern a decisively less coherent notion of environmental justice than the image and practices that later emerged (Borsatto and Carmo 2013; Houtzager 2005; Stédile and Fernandes 1999). Elites played subjugated peoples off one another to forward their own interests and undermine significant redistribution that would require their own sacrifice. This is a general tactic used far beyond the events surrounding the birth of the MST (Harvey 2007; Nixon 2011; Vergara-Camus 2014).

On the journey from sem-terra to com-terra, the frente de massa or MST vanguard sent into new regions of potential land gains often ran into indigenous populations already occupying those lands in a manner very different than the MST families sought to use the land. The illegibility of indigenous land use - their lack of fences, buildings, or extensive agriculture covering the full extent of the terrain they frequent for activities such as plant harvesting, fishing, and hunting - to the Brazilian government and its crusade for defensible land as well as for the MST families viewing ownership as signalled by distinctive marks of possession derived from colonialism, constitutes a major aspect of Brazil's environmental justice quandary (Zhouri 2010). Like many other places in Africa, Asia, and the Americas (and anywhere where semi-nomadic people dwell), sedentary agriculturalist practices are quickly becoming the lingua franca of land ownership, against which other forms of living or convivencia are glossed as deviant, wasteful, and backwards. The cult of productivity surrounding modern agriculture measures success by crop intensity. This metric undermines the claims of indigenous people to the vast areas they inhabit. The terra nullius model of land ownership which became the neoliberal doctrine of "effective use" codified in the 1988 Brazilian Constitution, works in concept if not in practice equally against the MST as it did against indigenous communities (Hendlin 2014b). The race against the land, maximising shortterm crop output at the cost of ecological and social health and resilience, can just as well be 
posed as an argument against the small land farming of minifúndios, favouring industrial farming. In the short-term at least, industrial farming can create pound-per-pound more food than smaller-scale farms, even if monocropping for export creates less ecological and social resilience than diverse subsistence crop production.

As Oliveira (2013) notes, the Brazilian government has a history of preventing and triaging land grabs in one part of the country while courting large-scale foreign agribusiness in others. This unreconciled policy dissonance has been consistent across Brazil's regimes, democratic and dictatorial. While the military government was more explicitly unresponsive to farmer and indigenous needs, since democratisation and even under the da Silva and Rousseff PDT governments, agribusiness interests have overridden indigenous and farmer opposition (Robles and Veltmeyer 2015). Despite public lip service to indigenous rights and social justice, hegemonic land practices have continued to advance in Brazil.

The MST and the Zapatista movement in Chiapas, México, comprise the formative global antiimperialist movements renegotiating the relationship between governments and underclasses (Vergara-Camus 2014). These movements' far-flung influences on the Occupy Wall Street movement, Greece's Direct Democracy Now movement, and Spain's Indignado movement (Tucker 2014), recommend critiquing the MST for the sake of environmental justice. The organising practices, multiple and direct venues in which they stake their claims, internal decision-making processes, and methods of commanding respect from establishments of power that otherwise would prefer to ignore or expropriate them, have all upset neoliberal hegemonic modes of power and created spaces of relative autonomy for collective self-determination. The MST is one of the few groups which - at least to some degree in certain periods - has managed to successfully control the political frame; elites cannot afford to dismiss their activities or exclude them wholly from decision-making processes, for the MST has managed to capture and maintain a moral high ground that has translated into political stature and material gains.

The situation for various indigenous groups in Brazil has not been as successful, unfortunately. Partly because of their lack of a unifying, popular political body, indigenous struggles against territorial dispossession have been checkered: certain internationally-well-connected tribes, such as the Kayapo have been granted sovereignty over their 22 million hectares (though this remains continually imperiled), while other tribes, such as the Yasuni (or Xingu), have been displaced, terrorised, and fragmented in cases where large infrastructure projects have outweighed indigenous rights (Dowie 2011).

In the past two decades, the MST has prudently broken the unholy pact the Brazilian dictatorial government wrought, pitting the MST against indigenous people and their commonly held land. As indigenous rights became a powerful bargaining chip vis-à-vis the international community, and indigenous land concessions from the government became a major form of land distribution backed by powerful transnational environmental organisations, the MST gladly partnered with these powerful interests, obtaining an allied mantle of environmental justice through mutual solidarity between the two oppressed groups.

\section{A heretical thought in environmental justice}

The irony that hegemonic structuring seeped into peasant-indigenous relations at the birth of the MST in Brazil, and in many other instances of pluralist environmental justice struggles, suggests that active work to decolonise power structures in environmental justice movements is critical (Tuck, McKenzie, and McCoy 2014). Environmental justice movements, like Standing Rock, would then become heterarchic and networked rather than hierarchical (Goldberg 2017).

What differentiates the environmental justice movement from the environmental movement, in part, is that environmental justice struggles "tended not to be about nature, per se, but about land use, social impact, [and] human health" (Szasz 1994, 40). It seems a categorical mistake for either movement to exclude the ecological or human aspects. Yet, to some extent, this has been 
perpetuated in environmental justice movements. This additional layer of hegemony rarely confronted in environmental justice that warrants consideration is ecological justice.

Wright and Wolford (2003, xxi) call "the contrast between laws mandating good land use and large landowners' actual, wasteful practices" embodied in Article 184 of the 1988 Constitution "Brazil's most profound legal contradiction". As codified in the Brazilian Constitution, the obsession with "using" land is a slippery slope from using up land (Hendlin 2014b). Starting from the unsustainable premises that land not yoked to commercial use is wasted, precludes any amount of redistribution from achieving equitable or sustainable outcomes. If unsustainable farming methods are employed to cope with hegemonic pressures to (over)produce, even hard-fought peasant landholdings will become quickly insufficient as they are exhausted, afflicting future generations (Hendlin 2014a). Branford and Rocha $(2002,51)$ note that the 1988 Constitution's "effective use clause", requiring that land fulfil its "social function" of income generation or else risk expropriation, marked a weakening of the military regime's previous land reform-leaning Land Statute, which "permitted the government to expropriate latifundios, defined either by size or land use, without any reference to 'social function'". As laudatory as this aim is for fulfilling the promise of omnia sunt communia when applied narrowly and instrumentally to latifundios, Article 184 entrenched an exploitative frame on the purpose of land. Article 184 failed to understand the ecological and social importance of so-called "unproductive" land as viewed through the lens of global financialisation.

Zero-sum game theory models encourage depletion of earth commons, urging a race against others to use up and therefore privatise as much of nature as possible before others do. In fact, even conservation of nature now has entered a justificatory scheme such that conservation has to be productive for biodiversity, carbon credits, ecosystem services, or some other abstract material concept keyed into economic utility (Maier 2017). Norgaard (2015, n.p.) has lamented that "uncritical economic creed has colonized other disciplines, including ecology, as ecologists increasingly rely on economistic logic to rationalize the protection of ecosystems". Even when land and nature is understood as a commons to be collectively managed and enjoyed for current and future generations, rather than as private land subject to the extractive whims of the owner, any reference to sustaining the good of the territory and its nonhuman inhabitants is subordinated to the desires and needs of collectivised human "owners" (Mishori 2014). The recursiveness of ecological justice to the human subject betrays the possibilities of a non-hegemonic environmental justice.

The compulsion to own land itself and ascribe property to the commons is often overlooked in postcolonial and indigenous studies focused on land rights. The aim of decolonialisation, it must be emphasised, is not to transfer "back" to indigenous people the land that colonising powers took away from them (Tuck, McKenzie, and McCoy 2014). No, the decolonisation movement's claim is that land cannot be owned in the first place (Tuck and Yang 2012). The movement's demand is to disband the property regime that keeps people and land apart and stuck in a tragedy of the commons-like "game".

If hegemony is understood as an integrated principle without a convenient beginning or end, then one might postulate that it starts inside as self-oppression at the top, within the hegemons themselves against themselves, and does not end merely with humans, but extends far beyond, exerting violence onto the more-than-human world (Abram 1996; Biesecker and Hoffmeister 2010; Plumwood 2002; Vetlesen 2015).

\section{Conclusion}

Pluralism in environmental justice is increasingly receiving the attention it deserves (Schlosberg 1999, 2007). Yet, the political act of solidarity in environmental justice movements remains forever fragile in the face of bargains with the state or corporations that provide concessions to one marginalised group at the expense of another. Furthermore, environmental justice groups are never just groups, but complex compositions of individual actors in which hegemonic structures are often reproduced, borrowing and lending agency, often without explicit consent. Precisely because the 
MST has proven to be a deeply reflective movement capable of solidarity with indigenous peoples exerting sovereignty over their native territories, as well as willing to confront sexism and other forms of bias within its own movement, it has met not only political success, but also worldwide admiration and support. That the MST arose out of a conflict in which the Brazilian dictatorship drove landless peasants to encroach on the territorial rights of an indigenous group, demonstrates that hegemonic structures are as fragile as solidarity. Yet, for the MST, as with other environmental justice movements working within colonial property rights regimes even as they work against them, the hard work of recognising and undoing the ramifying ways hegemony continues to play out within human groups and their relations with the land remains unfinished.

\section{Notes}

1. Also see Cox (1993). Laclau and Mouffe (1985) rightly note that in regarding and utilising the concept, hegemony is "not the majestic unfolding of an identity by the response to a crisis", but instead is inherent to the existing structure of power relations (7). In the case described here, one could imagine that the response described arose from the crisis of reconfiguring power after the end of historical colonialism (see Deutsch 1999).

2. The propensity for alternative structures to reproduce internally the violence hegemonic social structures impose externally is the very crux, ironically, of critiques of multiculturalism, cultures that exist separately but not outside dominant, hegemonic culture (Butler, Laclau, and Žižek 2000; Okin 1998; Parekh 2002).

3. The fazenda (or hacienda in Spanish-speaking Latin America) system is a remnant of the colonial latifundio land apportionment in Brazil and the rest of Latin America. However, every country in Latin America, with the exception of Brazil, has since independence subsequently undergone land reform. See Stédile and Fernandes (1999), for evidence that the MST emerged to disintegrate the fazenda system.

4. In "Chile, Argentina, [the] western United States and Canada, and non-coastal Brazil - new national stories served largely to justify and settle outline maps. They filled in the blank 'unoccupied' spaces with 'nationals' or at least demonstrated possession in some visible way" (Stephanson et al. 2009, 6). Grappling to legitimate politically one's own identity group as the truly national(ist) one is not a new event, but is continuous with the long history of colonialism.

5. See Dennett's very strange treatment of this topic in Dennett $(2002,2)$. He writes: "It was still possible in the 1960 s for a human being to live in a nation, and be subject to its laws, without the slightest knowledge of that fact".

6. Even as Brazil has experienced social democratic governments like that of Lula, the recent hostile take-over of the Rousseff presidency by what appear to be parties favouring the same constellations of power as Brazil's historical military dictatorship, demonstrates that the plutocratic colonial Brazilian fazendeiro power structure has evolved, while still rejecting restorative justice measures such as agricultural reform.

\section{Disclosure statement}

No potential conflict of interest was reported by the author.

\section{ORCID}

Yogi Hale Hendlin (D) http://orcid.org/0000-0002-1714-6132

\section{References}

Abram, D. 1996. The Spell of the Sensuous. New York: Vintage Books.

Agence France-Presse. 2017. Garimpeiros fazem massacre em tribo isolada do Amazonas, diz MP [WWW Document]. VEJA.com. Accessed September 11, 2017. http://veja.abril.com.br/brasil/garimpeiros-fazem-massacre-em-triboisolada-do-amazonas-diz-mp/.

Benford, R. D., and D. A. Snow. 2000. "Framing Processes and Social Movements: An Overview and Assessment." Annual Review of Sociology 26: 611-639. doi:10.1146/annurev.soc.26.1.611.

Biesecker, A., and S. Hoffmeister. 2010. "Focus: (Re)Productivity, Sustainable Relations Both Between Society and Nature and Between the Genders." Ecological Economics 69: 1703-1711. doi:10.1016/j.ecolecon.2010.03.025.

Borsatto, R. S., and M.S. do Carmo. 2013. "A construção do discurso agroecológico no Movimento dos Trabalhadores Rurais Sem-Terra (MST)." Revista de Economia e Sociologia Rural 51: 645-660. doi.org/10.1590/S0103-20032013000400002.

Branford, S., and O. Glock. 1986. The Last Frontier: Fighting over Land in the Amazon. London: Zed Books. 
Branford, S., and J. Rocha. 2002. Cutting the Wire: The Story of the Landless Movement in Brazil. London: Latin America Bureau.

Butler, J., E. Laclau, and S. Žižek. 2000. Contingency, Hegemony, Universality: Contemporary Dialogues on the Left. London: Verso.

Cole, L. W., and S. R. Foster. 2001. From the Ground Up: Environmental Racism and the Rise of the Environmental Justice Movement. 1st ed. New York: NYU Press.

CONCRAB, C. das C. da R.A. do B. 1995. Caderno de Cooperação Agrícola (No. 5), Sistema Cooperativista dos Assentados. São Paulo.

Cox, R. W. 1993. "Gramsci, Hegemony and International Relations: An Essay in Method." In Gramsci, Historical Materialism and International Relations, edited by S. Gill, 49-67. Cambrdige: Cambridge University Press.

Critchley, S., and O. Marchart. 2012. Laclau: A Critical Reader. London: Routledge.

Dennett, D. 2002. Freedom Evolves. 1st ed. New York: Viking Adult.

De Souza Martins, J. 2002. "Representing the Peasantry? Struggles for/about Land in Brazil." The Journal of Peasant Studies 29: 300-335. doi.org/10.1080/03066150412331311099.

De Souza Martins, J. 1990. "Rural Social Movements." In The Future of Amazonia: Destruction or Sustainable Development?, edited by D. Goodman and A. Hall. New York: Palgrave Macmillan.

Deutsch, S. 1999. Las Derechas: The Extreme Right in Argentina, Brazil, and Chile, 1890-1939. 1st ed. Stanford, CA: Stanford University Press.

DeVore, J. 2016. "The Landless Invading the Landless: Participation, Coercion, and Agrarian Social Movements in the Cacao Lands of Southern Bahia, Brazil." In Brazilian Agrarian Social Movements, edited by R. Tarlau and A. Pahnke, 133-155. London: Routledge.

Diomo, A. M. 1995. A Vez e Voz do Popular: Movimentos Sociais e Participação Política no Brasil Pós-70. ANPOCS/Relume Dumará, Rio de Janeiro.

Dowie, M. 2011. Conservation Refugees: The Hundred-Year Conflict Between Global Conservation and Native Peoples. Cambridge, MA: MIT Press.

Fairhead, J., M. Leach, and I. Scoones. 2012. "Green Grabbing: a new Appropriation of Nature?" The Journal of Peasant Studies 39: 237-261. doi:10.1080/03066150.2012.671770.

Fernandes, B. M. 2000. A formação do MST no Brasil. Petrópolis: Editora Vozes.

Fernandes, B. M. 2008. "O MST e as reformas agrárias do Brasil." Revista Osal A 9: 72-85.

Filho, A. O. S., J. M. Ramos, K. Oliveira, and T. N. Nascimento. 2015. "A Evolução do Código Florestal Brasileiro." Cadernos de Graduação Ciências Humanas e Sociais - UNIT 2: 271-290.

Fitzmaurice, A. 2014. Sovereignty, Property and Empire, 1500-2000. Cambridge: Cambridge University Press.

Fraser, N. 2003. "Social Justice in the age of Identity Politics: Redistribution, Recognition, and Participation." In Redistribution or Recognition? A Political-Philosophical Exchange, edited by N. Fraser and A. Honneth, 7-109. London: Verso.

Gamba, C., and W. Costa Ribeiro. 2017. "Conservação ambiental no Brasil: uma revisão crítica de sua institucionalização." Revista de Estudios Brasileños 4: 146-160. doi.org/10.3232/REB.2017.V4.N6.2556.

Goldberg, D. 2017. "Lessons from Standing Rock - Of Water, Racism, and Solidarity." The New England Journal of Medicine 376: 1403-1405. doi.org/10.1056/NEJMp1701248.

Gramsci, A. 1970. Selections From the Prison Notebooks by Antonio Gramsci Unknown Edition. London: Lawrence and Wishart.

Gramsci, A. 1999. The Prison Notebooks. London: Electric Book.

Harvey, D. 2006. Spaces of Global Capitalism: A Theory of Uneven Geographical Development. 1st ed. London: Verso.

Harvey, D. 2007. A Brief History of Neoliberalism. Oxford: Oxford University Press.

Hecht, S. B. 1989. Murder at the Margins of the World. New Left Rev. Accessed https://doi.org/10.1080/10714839.1989. 11724681

Hecht, S. 2015. "Smallholders, Forest Management and Rural Development in the Amazon." The Journal of Peasant Studies 42: 233-236. doi.org/10.1080/03066150.2014.978139.

Hecht, S. B., and A. Cockburn. 2010. The Fate of the Forest: Developers, Destroyers, and Defenders of the Amazon, Updated Edition. Chicago: University of Chicago Press.

Hendlin, Y. H. 2014a. "The Threshold Problem in Intergenerational Justice." Ethics and the Environment 19: 1-38.

Hendlin, Y. H. 2014b. "From Terra Nullius to Terra Communis: Reconsidering Wild Land in an Era of Conservation and Indigenous Rights." Environmental Philosophy 11: 141-174.

Hobsbawm, E., and T. Ranger, eds. 2012. The Invention of Tradition. Reissue ed. Cambridge: Cambridge University Press.

Houtzager, P. P. 2005. "The Movement of the Landless (MST), Juridical Field, and Legal Change in Brazil." In Law and Globalization From Below: Towards a Cosmopolitan Legality, edited by B. de S. Santos and C. A. Rodríguez-Garavito, 218-240. Cambridge: Cambridge University Press.

Jepson, W. 2006. "Private Agricultural Colonization on a Brazilian Frontier, 1970-1980." Journal of Historical Geography 32: 839-863. doi.org/10.1016/j.jhg.2004.12.019.

Johnston, H., and P. Almeida. 2006. Latin American Social Movements: Globalization, Democratization, and Transnational Networks. New York: Rowman \& Littlefield. 
Kujawa, H. A. 2015. "Conflitos envolvendo indígenas e agricultores no Rio Grande do Sul: dilemas de políticas públicas contraditórias." Ciências Sociais Unisinos 51. doi.org/10.4013/csu.2015.51.1.08.

Laclau, E., and C. Mouffe. 1985. Hegemony and Socialist Strategy: Towards a Radical Democratic Politics. London: Verso.

Maier, D. S. 2017. "Should Biodiversity and Nature Have to Earn Their Keep? What It Really Means to Bring Environmental Goods into the Marketplace." Ambio, 1-16. doi.org/10.1007/s13280-017-0996-5.

Maybury-Lewis, B. 1994. The Politics of the Possible: The Brazilian Rural Workers' Trade Union Movement, $1964-1985$. Philadelphia: Temple University Press.

Merlan, F. 2009. "Indigeneity: Global and Local." Current Anthropology 50: 303-333. doi.org/10.1086/597667.

Mishori, D. 2014. "Reclaiming Commons Rights: Resources, Public Ownership and the Rights of Future Generations." The Law \& Ethics of Human Rights 8. doi.org/10.1515/lehr-2014-0009.

Nixon, R. 2011. Slow Violence and the Environmentalism of the Poor. Cambridge, MA: Harvard University Press.

Norgaard, R. 2015. "The Church of Economism and Its Discontents." Great Transition Initiative. Accessed http://www. greattransition.org/publication/the-church-of-economism-and-its-discontents.

Okin, S. M. 1998. "Feminism and Multiculturalism: Some Tensions." Ethics 108: 661-684. doi:10.1086/233846.

Oliveira, G. 2013. "Land Regularization in Brazil and the Global Land Grab: Land Regularization in Brazil." Development and Change 44: 261-283. doi.org/10.1111/dech.12009.

Ostrom, E. 1990. Governing the Commons: The Evolution of Institutions for Collective Action. New York: Cambridge University Press.

Parekh, B. C. 2002. Rethinking Multiculturalism: Cultural Diversity and Political Theory. Cambridge, MA: Harvard University Press.

Perfecto, I., J. H. Vandermeer, and A. L. Wright. 2009. Nature's Matrix: Linking Agriculture, Conservation and Food Sovereignty. 1st ed. Sterling, VA: Earthscan.

Perruci, G. 1999. "'Green McWorld' Versus 'Gold Jihad': The Clash of Ideas in the Brazilian Amazon." Global Society 13: 163180. doi.org/10.1080/13600829908443185.

Plumwood, V. 2002. Environmental Culture: The Ecological Crisis of Reason, Environmental Philosophies Series. London: Routledge.

Poletto, I., and A. Canuto. 2002. Nas pegadas do povo da terra: 25 anos da Comissão Pastoral da Terra. São Paulo: Edições Loyola.

Robles, W., and H. Veltmeyer. 2015. The Politics of Agrarian Reform in Brazil: The Landless Rural Workers Movement. Dordrecht: Springer.

Schlosberg, D. 1999. Environmental Justice and the New Pluralism: The Challenge of Difference for Environmentalism. Oxford: Oxford University Press.

Schlosberg, D. 2007. Defining Environmental Justice: Theories, Movements and Nature. Oxford: Oxford University Press.

Schröder, I. W. 2016. "The Political Economy of Tribalism in North America: Neotribal Capitalism?" Anthropological Theory. doi.org/10.1177/146349960334003.

Scott, J. C. 1999. Seeing Like a State: How Certain Schemes to Improve the Human Condition Have Failed. New Haven: Yale University Press.

Soares-Filho, B., R. Rajão, M. Macedo, A. Carneiro, W. Costa, M. Coe, H. Rodrigues, and A. Alencar. 2014. "Cracking Brazil's Forest Code." Science 344: 363-364. doi.org/10.1126/science.1246663.

Stédile, J. P., and B. M. Fernandes. 1999. Brava gente: a trajetória do MST e a luta pela terra no Brasil. 1st ed. São Paulo: Editora Fundação Perseu Abramo.

Stephanson, A., C. Briones, J.P. de Oliveira, R. Nichols, J. E. Chamberlain, and R. White. 2009. Manifest Destinies and Indigenous Peoples. Cambridge, MA: David Rockefeller Center for Latin American Studies.

Stocks, A. 2005. "TOO MUCH FOR TOO FEW: Problems of Indigenous Land Rights in Latin America." Annual Review of Anthropology 34: 85-104. doi.org/10.1146/annurev.anthro.33.070203.143844.

Suárez, S. M. 2006. "Gender and Land." In Promised Land: Competing Visions of Agrarian Reform, edited by P. Rosset, R. Patel, and M. Courville, 192-207. Oakland, CA: Food First Books.

Szasz, A. 1994. Ecopopulism: Toxic Waste and the Movement for Environmental Justice. 1st ed. Minneapolis: University of Minnesota Press.

Tuck, E., M. McKenzie, and K. McCoy. 2014. "Land Education: Indigenous, Post-Colonial, and Decolonizing Perspectives on Place and Environmental Education Research." Environmental Education Research 20: 1-23. doi.org/10.1080/13504622. 2013.877708.

Tuck, E., and K. W. Yang. 2012. "Decolonization is not a Metaphor." Decolonization: Indigeneity, Education \& Society 1: 1-40.

Tucker, D. 2014. Are Mexico's Zapatista rebels still relevant? [WWW Document]. Al-Jazeera. Accessed December $18,2016$. http://www.aljazeera.com/indepth/features/2014/01/are-mexico-zapatista-rebels-still-relevant-20141183731812643.html.

Vergara-Camus, L. 2014. Land and Freedom: The MST, the Zapatistas and Peasant Alternatives to Neoliberalism. London: Zed Books.

Vetlesen, A. J. 2015. The Denial of Nature: Environmental Philosophy in the era of Global Capitalism. New York: Routledge.

Wright, A. L., and W. Wolford. 2003. To Inherit the Earth: The Landless Movement and the Struggle for a New Brazil. Oakland: Food First Books.

Zhouri, A. 2010. "“'Adverse Forces" in the Brazilian Amazon: Developmentalism Versus Environmentalism and Indigenous Rights." The Journal of Environment \& Development 19: 252-273. doi.org/10.1177/1070496510378097. 